\title{
Sugarcane Crop Residue and Bagasse Allelopathic Impact on Oat (Avena sative L.), Tall Morningglory (Ipomoea purpurea L. Roth), and Redroot Pigweed (Amaranthus retroflexus L.) Germination
}

\author{
Charles L. Webber III ${ }^{1}$, Paul M. White Jr. ${ }^{1}$, Douglas J. Spaunhorst ${ }^{1}$, Darcey G. Wayment ${ }^{2}$ \& Derek S. Landrum ${ }^{3}$ \\ ${ }^{1}$ Sugarcane Research Unit, USDA, Agriculture Research Service, Houma, LA, USA \\ ${ }^{2}$ Department of Physical Sciences, Nicholls State University, Thibodaux, LA, USA \\ ${ }^{3}$ LSU AgCenter, Louisiana State University, Orleans Parish, New Orleans, LA, USA \\ Correspondence: Charles L. Webber III, Sugarcane Research Unit, USDA, Agriculture Research Service, Houma, \\ LA 70360, USA. E-mail: chuck.webber@ars.usda.gov
}

Received: November 6, 2017

Accepted: December 2, 2017 Online Published: January 15, 2018

doi:10.5539/jas.v10n2p15

URL: https://doi.org/10.5539/jas.v10n2p15

\begin{abstract}
Allelopathy, the chemical interaction between plants, may result in the inhibition of plant growth and development, and includes compounds released from a primary crop that adversely impact crop or weed species. The objective of this research was to observe the allelopathic impact of sugarcane (Saccharum sp.) post-harvest crop residue and mill bagasse leachate on seed germination of three other plant species. Oat (Avena sative L.) var. 'Corral', tall morningglory (Ipomoea purpurea L. Roth), and redroot pigweed (Amaranthus retroflexus L.) seeds were treated with 5 leachate concentrations $(0,12.5,25,50$, and $100 \mathrm{~g} / \mathrm{L})$ from either sugarcane crop residue or sugarcane bagasse. Each experiment was repeated twice (Experiment $1 \& 2$ ) with each plant species, leachate concentrations, and leachate source (sugarcane crop residue and mill bagasse). The impact of leachates from sugarcane variety 'HoCP 96-540' crop residue and sugarcane bagasse differed by the species evaluated (oat, morningglory, and redroot pigweed), the leachate source (crop residue vs. bagasse), and leachate concentration $(0$ to $100 \mathrm{~g} / \mathrm{L})$. Oat germination was not affected leachate source or concentration. Germination for both weed species, tall morningglory and redroot pigweed, were adversely affected by leachate source and concentration. In both cases, the sugarcane crop residue leachate had a greater deleterious impact on germination than did the bagasse leachate. The response to the leachates was more consistent and severe for tall morningglory germination than redroot pigweed germination. Averaged across experiments, the $12.5 \mathrm{~g} / \mathrm{L}$ crop residue concentration decreased the tall morningglory germination to $17 \%$ compared to $34 \%$ germination for the bagasse leachate, and the $100 \mathrm{~g} / \mathrm{L}$ residue concentration reduce germination to $6 \%$ compared to $19 \%$ for bagasse $100 \mathrm{~g} / \mathrm{L}$ bagasse concentration. The $100 \mathrm{~g} / \mathrm{L}$ concentration of crop residue reduced redroot pigweed germination by $13 \%$ (Experiment 1 ) and $27 \%$ (Experiment 2), while the bagasse leachate reduced germination by $5 \%$ (Experiment 1) and 15\% (Experiment 2). Future research should investigate the allelopathic compounds present in the sugarcane crop residue and bagasse, determine if the same allelopathic compounds are present and in the same concentration among other sugarcane varieties, and further examine which weed and crop species may be vulnerable to the allelopathic compounds present in sugarcane crop residue and bagasse.
\end{abstract}

Keywords: allelopathy, pestiphytology, morningglory, redroot pigweed, seed germination, sugarcane

\section{Introduction}

\subsection{Allelopathy}

Many plant species, both crop and weed plants, are now known to produce compounds that when released into the environment can impact the growth and development of other plants (Rice, 1984). Allelopathy is the term used to describe this biochemical interaction between plants, whether inhibiting or stimulating plant growth and development (Molisch, 1937; Rice, 1984). There is a growing interest by the general public for naturally produced crops and, therefore, a positive incentive to explore the use of natural plant chemicals to either promote crop growth and production, or inhibit weed growth and development (Bowmick \& Doll, 1982; Rice, 1984; Russo et al., 1997a, 1997b; Webber et al., 2015a, 2015b, 2017a, 2017b, 2017c). Information gleaned from allelopathic compounds has been used to produce natural herbicides and develop synthesized herbicides which 
are closely related the allelopathic compounds (Duke \& Dayan, 2013; Cheema \& Khaliq, 2000; Gerwick \& Sparks, 2014).

Allelopathy can also adversely impact the same crop that is producing the allelopathic compounds (autotoxicity) when an annual crop is replanted in the same field or where a perennial crop is present multiple years (Putnam, 1985; Schreiner \& Reed, 1907). Examples of autotoxicity for annual crops include barley (Hordeum vulgare L.) (Ben-Hammouda et al., 2002), corn (Zea mays L.) (Almezori et al., 1999; Anderson \& Cruse, 1995), rice (Oryza sativa L.) (Chen et al., 2008; Chou \& Chiou, 1979; Dilday et al., 1994), winter wheat (Triticum aestivum L.) (Wu et al., 2001, 2007), and sorghum (Sorghum bicolor L. Moench) (Ben-Hammouda et al., 1995). Sorghum produces sorgoleone, an allelopathic compound that exhibits similar herbicidal activity as the commercial herbicide atrazine (Nimbal et al., 1996). Examples of perennial crops exhibiting autotoxicity include alfalfa (Medicago sativa L.) (Chung \& Miller, 1995; Hedge \& Miller, 1990), asparagus (Asparagus officinalis L.) (Motoki et al., 2002), and sugarcane (Saccharum sp.) (Viator et al., 2006).

\subsection{Sugarcane and Allelopathy}

Allelopathic compounds have been detected in leachates from sugarcane leaves in several studies (De Carvalho et al., 1996; Singh et al., 2003; Viator et al., 2006). For example, Viator et al. (2006) identified benzoic acid from post-harvest sugarcane crop residue, variety 'LCP $85-384$ '. Benzoic acid and its derivatives have been shown to be allelopathic to cotton (Gossypium hirsutum L.) (Lodhi et al., 1987), wheat (Lodhi et al., 1987) and ryegrass (Lolium spp.) (Wu et al., 2002) and dicamba, a commercial herbicide, is a benzoic acid compound. In addition, the allelopathic compounds of ferulic, vanillic and syringic acids have been isolated from sugarcane crop residue leachates (Sampietro et al., 2005; Sampietro \& Vattuone, 2006b). Phenolic compounds, used in commercial herbicides (i.e. bromoxynil and isonil), have been isolated from sugarcane leaves (Sampieto \& Vattuone, 2006a).

Sugarcane crop residue leachates reduced germination and radical growth of the field crops oat (Avena nuda L.), (Viator et al., 2006), rye (Secale cereale L.) (Viator et al., 2006), sorghum (Sorghum bicolor L. Moench) (Sampietro \& Vattuone, 2006b), and wheat (Triticum aestivum L.) (Sampietro \& Vattuone, 2006b); the vegetable crops tomato (Solanum lycopersicum L.) (Webber et al., 2017b), Chinese kale (Brassica oleracea L. var. alboglabra Bailey) (Webber et al., 2017b), cucumber (Cucumis sativus L.) (Webber et al., 2017b), and radish (Raphanus sativus L.) (Sampietro \& Vattuone, 2006b); and the weeds arrowleaf sida (Sida rhombifolia L.) (Sampietro et al., 2007), pigweed (Amaranthus quitensis L.) (Sampietro \& Vattuone, 2006b), redroot pigweed (Amaranthus retroflexus L.) (Webber et al., 2017c), spiny pigweed (Amaranthus spinosus L.) (Webber et al., 2017c), wild mustard (Brassica campestris L.) (Sampietro \& Vattuone, 2006b), tall morningglory (Ipomoea purpurea L. Roth) (Viator et al., 2006), and red morningglory (Ipomoea coccinea L.) (Webber et al., 2017c).

Webber et al. (2017c) was the first to document that sugarcane root leachate were allelopathic. In a bioassay experiment, the highest root concentration tested $(100 \mathrm{~g} / \mathrm{L})$ decreased red morningglory and redroot pigweed germination by $20 \%$ and $19 \%$, respectively, while spiny amaranth germination was unaffected (Webber et al., 2017c). In addition to the sugarcane leaves and roots, Rodrigues et al. (2001) documented that the breakdown of sugarcane bagasse lignocellulosic material produced toxic compounds that inhibit cellular growth. Others have indicated that the leaching or the microbial breakdown of the bagasse may have an allelopathic (toxic) impact on squash plants (Facelli \& Pickett, 1991; Rice, 1984; Rodrigues et al., 2001; Webber et al., 2017a) and tomato (Webber et al., 2017b). Research was initiated to determine the allelopathic impact of sugarcane crop residue and sugarcane bagasse leachates on the germination of three plant species (oat, morningglory, and redroot pigweed).

\section{Material and Methods}

\subsection{Plant Material Collection}

Sugarcane var. 'HoCP 96-540' (Tew et al., 2005) crop residue (straw) was collected at the USDA, ARS, Sugarcane Research Unit, Ardoyne Farm, Schriever, LA, immediately after harvesting the sugarcane in 2015. Since 2008, HoCP 96-540 has been planted to more hectares in Louisiana than any other sugarcane variety (Gravois, 2014). The crop residue averaged $716 \mathrm{~g} / \mathrm{m}^{2}(71.6 \mathrm{mt} / \mathrm{ha}$ ) on an oven dry weight basis, which included leaves, immature nodes and growing tips. Sugarcane mill bagasse was collected from the Raceland Raw Sugar Corporation mill in Raceland, LA, in March of 2016. Sugarcane bagasse is the fibrous material remaining after removing the sucrose, water, and other impurities (filter mud) from the millable sugarcane.

\subsection{Sugarcane Leachate Preparations}

The sugarcane crop residue and bagasse were dried in a forced air oven at $60^{\circ} \mathrm{C}$ to a constant weight. The dried material was then ground using a Thomas-Wiley Laboratory Mill with a 2-mm sieve. The plant materials and 
deionized water were added to 4000-ml flasks and placed on a Lab-Line Orbit Shaker at $100 \mathrm{rpm}$ for $12 \mathrm{~h}$ at room temperature $\left(22^{\circ} \mathrm{C}\right)$. The extracts were vacuum filtered using a three step process; 1$)$ filtered through a Buchner funnel sans filter paper, 2) Buchner funnel with a VWR Qualitative, 417 filter (9.0 cm diameter), and 3) Buchner funnel with a Whatman ${ }^{\circledR} \# 2$ filter $(9.0 \mathrm{~cm}$ diameter). The samples were then diluted as needed with deionized water to produce concentrations of $100 \mathrm{~g} / \mathrm{L}$ (full strength), $50 \mathrm{~g} / \mathrm{L}$ (half strength), $25.0 \mathrm{~g} / \mathrm{L}$ (quarter strength) and $12.5 \mathrm{~g} / \mathrm{L}$ (eighth strength) extracts of sugarcane roots and sugarcane crop residue (Webber et al., 2005a, 2005b, 2017b). The $\mathrm{pH}$ for all dilutions was adjusted to 7.0 using $1 \mathrm{M} \mathrm{KOH}$ and $5 \% \mathrm{C}_{2} \mathrm{H}_{4} \mathrm{O}_{2}$ (acetic acid).

\subsection{Leachate Treatments of the Seeds}

The oat (Avena sativa L.) var. 'Corral' was purchased from Seedway (Hall, NY, USA). The tall morningglory (Ipomoea purpurea L. Roth) seed was purchased from Eden Brothers (Asheville, NC, USA), while the redroot pigweed (Amaranthus retroflexus L.) seed was purchased from River Refuge Seed Company (Brownsville, OR, USA). The tall morningglory and redroot pigweed seed were surface sterilized for 1 min using a $50 \%$ bleach (6\% sodium hypochlorite) $50 \%$ deionized water solution. The seeds were then rinsed with deionized water and allowed to air dry for $10 \mathrm{~min}$. A preliminary germination test determined that the oat seed was adversely impacted by the surface sterilization, therefore the oat seed was not surface sterilized in this experiment. Twenty seeds of each plant species were placed in separate Petri plates which contained $9.0 \mathrm{~cm}$ Whatman ${ }^{\circledR}$ No. 2 filter papers. To each Petri plate was added $10 \mathrm{ml}$ of either sugarcane crop residue or bagasse at each of the concentrations [ 0 (deionized water), 12.5, 25, 50, and $100 \mathrm{~g} / \mathrm{L}$ ]. The Petri plates were covered and placed in a non-illuminated incubator at $27{ }^{\circ} \mathrm{C}$. After $7 \mathrm{~d}$ the Petri plates were removed and seed germination was measured. Seeds were considered germinated when the seed radicle was equal to or greater than the length of the width of the seed of the specific plant species being measured. The experimental design for each of the 3 plant species (oat, morning glory, and redroot pigweed) were RCBD which included 2 sources of leachates (sugarcane crop residue and sugarcane bagasse) and 5 treatment leachate concentrations $(0,12.5,25,50$, and $100 \mathrm{~g} / \mathrm{L})$. Each germination experiment was repeated twice with 5 replications in each experiment. All data were subjected to PROC ANOVA and mean separation using LSD with $\mathrm{P}=0.05$ (SAS Inc., SAS, Ver. 9.4, Cary, NC).

\section{Results and Discussion}

\subsection{Statistical Analysis}

Significant interactions existed among plant species (oat, tall morningglory, and redroot pigweed), extract concentration $(0,12.5,25,50$, and $100 \mathrm{~g} / \mathrm{L})$, and experiments (Table 1); therefore, the plant species will be discussed separately, and, where necessary, the experiments will be discussed individually (Tables 2,3 , and 4).

Table 1. Analysis of variance (ANOVA) for percentage germination of oat, tall morningglory, redroot pigweed for source factors experiments, treatments, and experiment $\times$ treatment

\begin{tabular}{llll}
\hline Source & Oat & Tall Morningglory & Redroot Pigweed \\
\hline & $\operatorname{Pr}>\mathrm{F}$ & $\operatorname{Pr}>\mathrm{F}$ & $\operatorname{Pr}>\mathrm{F}$ \\
Experiment & $0.1927^{\mathrm{Z}}$ & 0.0175 & $<.0001$ \\
Treatment & $0.6415^{\mathrm{Z}}$ & $<.0001$ & $<.0001$ \\
Experiment $\times$ Treatment & $0.7964^{\mathrm{Z}}$ & $0.079^{\mathrm{Z}}$ & 0.0081 \\
\hline
\end{tabular}

Note. ${ }^{\mathrm{Z}}$ Not Significantly Different at $\mathrm{P}=0.05$, PROC ANOVA.

\subsection{Oat Germination}

There were no significant interactions between experiments (1 and 2) and the leachate concentrations for oat germination; therefore, the oat germination results will be discussed by experiment and averaged across experiments (Tables 1 and 2). There were no significant differences among sugarcane residue and bagasse leachates, leachate concentration within experiment 1, 2, or averaged across both experiments (Table 2). These results are in contrast to Viator et al. (2006) who reported that a sugarcane crop residue variety 'LCP 85-384' significantly decreased oat (Avena nuda L.) var. 'Rodeo' when comparing the control, ( $0 \%$ concentration) to the $25 \%$ and $100 \%$ leachate concentrations.

Although, the sugarcane variety ' $\mathrm{HoCP} 96-540$ ', which was used in our research, is a complex hybrid derived from crossing 'LCP 85-384' and 'LCP 86-454' (Tew et al., 2005), Wu et al. (2002) determined that allelopathic compounds, their concentration, and bioassay impact can vary across crop varieties. In addition, the oat seed used in the two experiments were very different, actually two different species. Viator et al. (2006) used Avena 
nuda L. oat species, which is usually referred to as "naked oat" because it produces a hulless oat seed with only fine hairs called trichomes on the seed. The "common oat" (Avena sativa L.) seed used in our research in contrast is a widely cultivated specie with seed husks. If wheat varieties of the same species have been shown to respond differently to allelopathic compounds (Sampietro \& Vattuone, 2006b), then different oat species could vary in sensitivity to allelopathic compounds, especially when exhibiting such physiological and anatomically differences between oat species.

Table 2. Impact of sugarcane ('HoCP 96-540') crop residue and sugarcane bagasse leachate concentrations on oat (Avena sative L.) var. 'Corral' germination percentage

\begin{tabular}{|c|c|c|c|}
\hline Extract Source \& Concentration & $\begin{array}{l}\text { Oat Germination } \\
\text { Experiment } 1\end{array}$ & $\begin{array}{l}\text { Oat Germination } \\
\text { Experiment } 2\end{array}$ & $\begin{array}{l}\text { Oat Germination } \\
\text { Averaged Across Experiments }\end{array}$ \\
\hline & $\%$ & $\%$ & $\%$ \\
\hline \multicolumn{4}{|l|}{ Crop Residue } \\
\hline $0 \mathrm{~g} / \mathrm{L}$ & $71 \mathrm{a}^{\mathrm{Z}}$ & $78 \quad \mathrm{a}$ & $74.5 \mathrm{a}$ \\
\hline $12.5 \mathrm{~g} / \mathrm{L}$ & 55 a & $72 \mathrm{a}$ & $63.5 \mathrm{a}$ \\
\hline $25 \mathrm{~g} / \mathrm{L}$ & $67 \quad \mathrm{a}$ & $73 \mathrm{a}$ & $70.0 \quad \mathrm{a}$ \\
\hline $50 \mathrm{~g} / \mathrm{L}$ & $70 \quad \mathrm{a}$ & $68 \mathrm{a}$ & $69.0 \quad \mathrm{a}$ \\
\hline $100 \mathrm{~g} / \mathrm{L}$ & $65 \mathrm{a}$ & $66 \mathrm{a}$ & $65.5 \mathrm{a}$ \\
\hline \multicolumn{4}{|l|}{ Bagasse } \\
\hline $0 \mathrm{~g} / \mathrm{L}$ & $71 \mathrm{a}$ & $78 \mathrm{a}$ & $74.5 \quad \mathrm{a}$ \\
\hline $12.5 \mathrm{~g} / \mathrm{L}$ & $68 \mathrm{a}$ & $68 \mathrm{a}$ & $68.0 \quad \mathrm{a}$ \\
\hline $25 \mathrm{~g} / \mathrm{L}$ & $58 \quad \mathrm{a}$ & $69 \mathrm{a}$ & $63.5 \mathrm{a}$ \\
\hline $50 \mathrm{~g} / \mathrm{L}$ & $73 \mathrm{a}$ & $74 \mathrm{a}$ & $73.5 \mathrm{a}$ \\
\hline $100 \mathrm{~g} / \mathrm{L}$ & $69 \mathrm{a}$ & $64 \mathrm{a}$ & $66.5 \mathrm{a}$ \\
\hline
\end{tabular}

Note. ${ }^{\mathrm{Z}}$ Means in a column followed by the same lower case letter are not significantly different at $\mathrm{P}=0.05$, ANOVA.

\subsection{Tall Morningglory Germination}

There were no significant interactions between experiments (1 and 2) and the leachate concentrations for tall morningglory germination; therefore, the tall morningglory germination results will be discussed by experiment and averaged across experiments (Tables 1 and 3).

Sugarcane crop residue and bagasse leachates reduced tall morningglory germination in experiments 1 and 2 , and when averaged across experiments as the leachate concentrations increased from $0 \mathrm{~g} / \mathrm{L}$ to $100 \mathrm{~g} / \mathrm{L}$ (Table 3 ). The decline in germination was more immediate and greater in extent for the crop residue than the bagasse leachates. When averaged across experiments, the $12.5 \mathrm{~g} / \mathrm{L}$ crop residue concentration decreased the tall morningglory germination to $17 \%$ compared to $34 \%$ germination for the bagasse leachate, and the $100 \mathrm{~g} / \mathrm{L}$ residue concentration reduce germination to $6 \%$ compared to $18.5 \%$ for bagasse $100 \mathrm{~g} / \mathrm{L}$ bagasse concentration (Table 3).

The sugarcane crop residue extracts results are consistent with earlier research by Viator et al. (2006), which showed that increasing sugarcane (var. 'LCP 85-384') crop residue leachate concentrations in a Commerce silt loam (fine-silty, mixed, nonacid, thermic Aeric Fluvaquents) soil decreased tall morningglory germination. Viator et al. (2006) also reported that the same leachate concentrations in a higher clay content soil, Sharkey clay, (very-fine, montmorillonitic, nonacid, thermic Vertic Haplaquepts) the sugarcane crop residue leachates did not decrease tall morningglory germination. Webber et al. (2017c) determined that sugarcane (variety 'HoCP 96-540') crop residue leachates decreased red morningglory (Ipomoea coccinea L.) germination by $29 \%$ at the $100 \mathrm{~g} / \mathrm{L}$ concentration. 
Table 3. Impact of sugarcane crop residue and bagasse leachate concentrations on tall morningglory (Ipomoea purpurea L. Roth) germination percentage

\begin{tabular}{|c|c|c|c|}
\hline Extract Source \& Concentration & $\begin{array}{l}\text { Tall Morningglory Germination } \\
\text { Experiment } 1\end{array}$ & $\begin{array}{l}\text { Tall Morningglory Germination } \\
\text { Experiment } 2\end{array}$ & $\begin{array}{l}\text { Tall Morningglory Germination } \\
\text { Averaged Across Experiments }\end{array}$ \\
\hline & $\%$ & $\%$ & $\%$ \\
\hline \multicolumn{4}{|l|}{ Crop Residue } \\
\hline $0 \mathrm{~g} / \mathrm{L}$ & $45.00 \quad \mathrm{a}^{\mathrm{Z}}$ & 51.00 & $48.0 \quad \mathrm{a}$ \\
\hline $12.5 \mathrm{~g} / \mathrm{L}$ & $19.00 \mathrm{~cd}$ & $15.00 \mathrm{~cd}$ & $17.0 \mathrm{~cd}$ \\
\hline $25 \mathrm{~g} / \mathrm{L}$ & $11.00 \mathrm{de}$ & $10.00 \mathrm{de}$ & $10.5 \mathrm{de}$ \\
\hline $50 \mathrm{~g} / \mathrm{L}$ & $11.00 \mathrm{de}$ & 6.00 & 8.5 \\
\hline $100 \mathrm{~g} / \mathrm{L}$ & 6.00 & 6.00 & 6.0 \\
\hline \multicolumn{4}{|l|}{ Bagasse } \\
\hline $0 \mathrm{~g} / \mathrm{L}$ & 45.0 & 51.0 & $48.0 \quad \mathrm{a}$ \\
\hline $12.5 \mathrm{~g} / \mathrm{L}$ & $31.00 \mathrm{bc}$ & 37.00 & $34.0 \quad \mathrm{~b}$ \\
\hline $25 \mathrm{~g} / \mathrm{L}$ & $37.00 \quad a b$ & 49.00 & $43.0 \quad \mathrm{a}$ \\
\hline $50 \mathrm{~g} / \mathrm{L}$ & $21.00 \mathrm{~cd}$ & 37.00 & $29.0 \quad b$ \\
\hline $100 \mathrm{~g} / \mathrm{L}$ & $14.00 \mathrm{de}$ & $23.00 \quad \mathrm{c}$ & $18.5 \mathrm{c}$ \\
\hline
\end{tabular}

Note. ${ }^{\mathrm{Z}}$ Means in a column followed by the same lower case letter are not significantly different at $\mathrm{P}=0.05$, ANOVA.

\subsection{Redroot Pigweed Germination}

There was a significant interaction between experiments (1 and 2) (Table 1) and the leachate concentrations for redroot pigweed germination; therefore, the redroot pigweed germination results will be discussed by experiment (Table 4). Sugarcane crop residue and bagasse leachates reduced redroot pigweed germination in experiments 1 and 2, but at greater extent for the sugarcane crop residue than the sugarcane bagasse leachates (Table 4). The $100 \mathrm{~g} / \mathrm{L}$ concentration of crop residue reduced germination by 13\% (Experiment 1) and 27\% (Experiment 2), while the bagasse leachate reduced germination by $5 \%$ (Experiment 1 ) and 15\% (Experiment 2) (Table 4). These results are congruence with research by Webber et al. (2017c) where $100 \mathrm{~g} / \mathrm{L}$ sugarcane (variety 'HoCP 96-540') crop residue leachates decreased redroot pigweed germination by $17.5 \%$ averaged across two experiments. The sugarcane crop residue results are similar to Webber et al. (2015a) who reported a corresponding decrease in redroot pigweed germination as kenaf leaf extracts increased from $0 \mathrm{~g} / \mathrm{L}$ to $66.7 \mathrm{~g} / \mathrm{L}$ and Panasiuk et al. (1986) and Yarnia et al. (2009) where sorghum residue and root extracts reduced redroot pigweed germination.

Table 4. Impact of sugarcane crop residue and bagasse leachate concentrations on redroot pigweed (Amaranthus retroflexus L.) germination percentage

\begin{tabular}{|c|c|c|c|c|c|}
\hline \multirow[t]{2}{*}{ Extract Source \& Concentration } & \multicolumn{2}{|c|}{$\begin{array}{l}\text { Redroot Pigweed Germination } \\
\text { Experiment } 1\end{array}$} & \multicolumn{2}{|c|}{$\begin{array}{l}\text { Redroot Pigweed Germination } \\
\text { Experiment } 2\end{array}$} & \multirow{2}{*}{$\begin{array}{l}\text { Redroot Pigweed Germination } \\
\text { Averaged Across Experiments } \\
\%\end{array}$} \\
\hline & $\%$ & & $\%$ & & \\
\hline \multicolumn{6}{|l|}{ Crop Residue } \\
\hline $0 \mathrm{~g} / \mathrm{L}$ & & $a^{z}$ & 75 & a & 62.0 \\
\hline $12.5 \mathrm{~g} / \mathrm{L}$ & 55 & a & 72 & a & 63.5 \\
\hline $25 \mathrm{~g} / \mathrm{L}$ & 51 & a & 60 & $\mathrm{bc}$ & 55.5 \\
\hline $50 \mathrm{~g} / \mathrm{L}$ & 50 & a & 55 & $\mathrm{~cd}$ & 52.5 \\
\hline $100 \mathrm{~g} / \mathrm{L}$ & 36 & $\mathrm{bc}$ & 48 & d & 42.0 \\
\hline \multicolumn{6}{|l|}{ Bagasse } \\
\hline $0 \mathrm{~g} / \mathrm{L}$ & 49 & a & 75 & a & 62.0 \\
\hline $12.5 \mathrm{~g} / \mathrm{L}$ & 47 & $a b$ & 50 & $\mathrm{~cd}$ & 48.5 \\
\hline $25 \mathrm{~g} / \mathrm{L}$ & 48 & $a b$ & 68 & $a b$ & 58.0 \\
\hline $50 \mathrm{~g} / \mathrm{L}$ & 33 & $\mathrm{c}$ & 66 & $a b$ & 49.5 \\
\hline $100 \mathrm{~g} / \mathrm{L}$ & 44 & $a b c$ & 60 & $\mathrm{bc}$ & 52.0 \\
\hline
\end{tabular}

Note. ${ }^{\mathrm{Z}}$ Means in a column followed by the same lower case letter are not significantly different at $\mathrm{P}=0.05$, ANOVA. 


\section{Conclusions}

The impact of leachates from sugarcane variety ' $\mathrm{HoCP} 96-540$ ' crop residue and sugarcane bagasse differed by the species evaluated (oat, tall morningglory, and redroot pigweed), the leachate source (crop residue vs. bagasse), and leachate concentration ( 0 to $100 \mathrm{~g} / \mathrm{L}$ ). The oat (Avena sativa $\mathrm{L}$.) germination was not affected by either the source of the leachate or the leachate concentration. This was in contrast to earlier research that resulted in a decrease in germination for a different oat species "naked oat" (Avena nuda L.) (Viator et al., 2006). The differences in the impact of the leachates on germination may be a result of using different oat species, seed viability, and/or sugarcane varieties. Future research should use both sugarcane varieties and evaluate germination on both oat species.

Germination for both weed species, tall morningglory and redroot pigweed, was adversely affected by leachate source and concentration. In both cases, the sugarcane crop residue leachates had a more deleterious impact on germination than did the bagasse leachate. This research suggests that the sugarcane crop residue has potential for reducing tall morningglory and redroot pigweed populations and competition due to the crop residue remaining on the field following harvest. The response to the leachates was more consistent and severe on tall morningglory germination than on redroot pigweed germination. The authors suggest the use of $100 \mathrm{~g} / \mathrm{L}$ sugarcane crop residue leachate concentration as a potential organic weed control method for decreasing tall morningglory germination and competition. Future research should investigate the allelopathic compounds present in the sugarcane crop residue and bagasse, determine if the same allelopathic compounds are present and in the same concentration among other sugarcane varieties, and further examine which weed and crop species may be vulnerable to the allelopathic compounds present sugarcane crop residue and bagasse.

\section{Trade Names or Commercial Products}

Mention of trade names or commercial products in this publication is solely for the purpose of providing specific information and does not imply recommendation or endorsement by the U.S. Department of Agriculture.

\section{EEO/Non-Discrimination Statement}

The U.S. Department of Agriculture (USDA) prohibits discrimination in all its programs and activities on the basis of race, color, national origin, age, disability, and where applicable, sex, marital status, familial status, parental status, religion, sexual orientation, genetic information, political beliefs, reprisal, or because all or part of an individual's income is derived from any public assistance program. (Not all prohibited bases apply to all programs.) Persons with disabilities who require alternative means for communication of program information (Braille, large print, audiotape, etc.) should contact USDA's TARGET Center at (202) 720-2600 (voice and TDD). To file a complaint of discrimination, write to USDA, Director, Office of Civil Rights, 1400 Independence Avenue, S.W., Washington, D.C. 20250-9410, or call (800) 795-3272 (voice) or (202) 720-6382 (TDD). USDA is an equal opportunity provider and employer.

\section{References}

Almezori, H. A., Al-Saadawi, I. S., \& Al-Hadithi, R. T. (1999). Allelopathic effects of corn residues on the subsequent corn crop. Allelopathy J., 6(2), 193-200.

Anderson, I. C., \& Cruse, R. M. (1995). Tillage and allelopathic aspects of the corn-soybean rotation effect. In A. Inderjit, M. Dakshini, \& F. A. Einhellig (Eds.), Allelopathy: Organisms, processes, and applications (ACS Symp. Ser. 582, pp. 184-192). Am. Chem. Soc., Washington, DC. https://doi.org/10.1021/bk-19950582.ch014

Ben-Hammouda, M., Ghorbal, H., Kremer, R. J., \& Oueslatt, O. (2002). Autotoxicity of barley. J. of Plant Nutrition, 25(6), 1155-1161. https://doi.org/10.1081/PLN-120004379

Ben-Hammouda, M., Kremer, R. J., \& Minor, H. C. (1995). Phytotoxicity of extracts from sorghum plant components on wheat seedling. Crop Sci., 35, 1652-1656. https://doi.org/10.2135/cropsci1995.0011183 $\mathrm{X} 003=500060023 \mathrm{x}$

Bowmick, P. C., \& Doll, J. D. (1982). Corn and soybean response to allelopathic effects of weed and crop residues. Agron. J., 74, 601-606. https://doi.org/10.2134/agronj1982.00021962007400040005x

Cheema, Z. A., \& Khaliq, A. (2000). Use of sorghum allelopathic properties to control weeds in irrigated wheat in a semi arid region of Punjab. Agriculture, Ecosystems \& Environment, 79(2), 105-112. https://doi.org/ $10.1016 / \mathrm{S} 0167-8809(99) 00140-1$

Chen, X. H., Hu, F., \& Kong, C. H. (2008). Varietal improvement in rice allelopathy. Allelopathy J., 22(2), 379-384. 
Chou, C. H., \& Chiou, S. J. (1979). Autointoxication mechanism of Oryza sativa. II. Effects of culture treatments on the chemical nature of paddy soil and on rice productivity. J. Chem. Ecol., 5, 839-859. https://doi.org/ 10.1007/BF00986568

Chung, I. M., \& Miller, D. A. (1995). Differences in autotoxicity among seven alfalfa cultivars. Agron. J., 87, 596-600. https://doi.org/10.2134/agronj1995.00021962008700030034x

De Carvalho, G. J., De BastosAndrade, L. A., Gomide, M. B., \& De Figueiredo, P. A. M. (1996). Allelopathic potential of senescent leaves and green leaves and tips of sugarcane, in different concentrations of dry matter, upon the germination of lettuce seeds. Unimar Ciences, 5(2), 19-24.

Dilday, R., Lin, J., \& Yan, W. (1994). Identification of allelopathy in USDA-ARS rice germplasm collection. Australian Journal of Experimental Agriculture, 34, 907-910. https://doi.org/10.1071/EA9940907

Duke, S. O., \& Dayan, F. E. (2013). Clues to new herbicide mechanisms of action from natural sources. In J. Beck, J. Coats, S. O. Duke, \& M. Koivunen (Eds.), Pest Management with Natural Products (Vol. 1141, pp. 203-215). American Chemical Society, Washington, DC. https://doi.org/10.1021/bk-2013-1141.ch014

Facelli, J. M., \& Pickett, S. T. A. (1991). Plant litter: Its dynamics and effects on plant community structure. Bot. Rev., 57(1), 1-32. https://doi.org/10.1007/BF02858763

Gerwick, B. C., \& Sparks, T. C. (2014). Natural products for pest control: An analysis of their role, value and future. Pest Management Science, 70(8), 1169-1185. https://doi.org/10.1002/ps.3744

Gravois, K. (2014). Sugarcane production handbook 2014 (p. 84). LSU AgCenter. Retrieved from http:/www.lsuagcenter.com/NR/rdonlyres/807E6478-E556-44A8-8440-16A2CC4BFD4C/94894/SUGAR CANEPRODUCTIONHANDBOOK.pdf

Hedge, R. S., \& Miller, D. A. (1990). Allelopathy and autotoxicity in alfalfa: Characterization and effects of preceding crops and residue incorporation. Crop Sci., 30, 1255-1259. https://doi.org/10.2135/cropsci1990.0 011183X003000060020x

Lodhi, M. A. K., Bilal, R., \& Malik, K. A. (1987). Allelopathy in agroecosystems: Wheat phytotoxicity and possible roles in crop rotation. J. Chem. Ecol., 13(8), 1881-1891. https://doi.org/10.1007/BF01013237

Molisch, H. (1937). Der einfluss einer pflanze auf die andere. Allelopathic Fischer, Jena.

Motoki, S., Ozawa, T., Hattori. T., Komatsu, K., Tsukada, M., Hattori, T., Komura, T., \& Oka, J. (2002). Allelopathy in asparagus 1: Reduction of the allelopathic effect on asparagus by the flowable agent in activated carbon. Acta. Hortic., 589, 381-386. https://doi.org/10.17660/ActaHortic.2002.589.54

Nimbal, C. I., Yerkes, C. N., Weston, L. A., \& Weller, S. C. (1996). Herbicidal activity and site of action of the natural product sorgoleone. Pesticide Biochemistry and Physiology, 54(1), 73-83. https://oi.org/10.1006/ pest. 1996.0011

Putnam, A. R. (1985). Allelopathic research in agriculture: Past highlights and potential. In A. C. Thompson (Ed.), The chemistry of allelopathy: Biochemical interactions among plants (pp. 1-8). American Chemical Society, Washington, D.C. https://doi.org/10.1021/bk-1985-0268.ch001

Rice, E. L. (1984) Allelopathy (2nd ed., p. 422). Acedemic Press, New York.

Rodrigues, R. C. L. B., Felipe, M. G. A., Silva, J. B., Vitolo, M., \& Gómez, P. V. (2001). The influence of pH, temperature and hydrolyzate concentration on the removal of volatile and nonvolatile compounds from sugarcane bagasse hemicellulosic hydrolyzate treated with activated charcoal before or after vacuum evaporation. Brazilian Journal of Chemical Engineering, 18(3), 299-311. https://doi.org/10.1590/S0104-663 22001000300009

Russo, V. M., Cartwright, C., \& Webber III, C. L. (1997a). Mulching effects on erosion of soil beds and on yield of autumn and spring planted vegetables. Biological Agriculture and Horticulture, 14, 85-93. https://doi.org/10.1080/01448765.1997.9754799

Russo, V. M., Webber III, C. L., \& Myers, D. L. (1997b). Kenaf extract affects germination and post-germination development of weed, grass and vegetable seeds. Ind. Crops Prod., 6, 59-69. https://doi.org/10.1016/ S0926-6690(96)00206-3

Sampietro, D. A., \& Vattuone, M. A. (2006a). Nature of the interference mechanism of sugarcane (Saccharum officinarum L.) straw. Plant Soil, 280, 157-169. https://doi.org/10.1007/s11104-005-2856-5 
Sampietro, D. A., \& Vattuone, M. A. (2006b). Sugarcane straw and its phytochemicals as growth regulators of weed and crop plants. Plant Growth Regul., 48, 21-27. https://doi.org/10.1007/s10725-005-5135-9

Sampietro, D. A., Sgariglia, M. A., Soberón, J. R., Quiroga, E. N., \& Vattuone, M. A. (2007). Role of sugarcane straw allelochemicals in the growth suppression of arrowleaf sida. Environmental and Experimental Botany, 60, 495-503. https://doi.org/10.1016/j.envexpbot.2007.02.002

Sampietro, D. A., Vattuone, M. A., \& Isla, M. I. (2005). Plant growth inhibitors isolated from sugarcane (Saccharum officinarum L.) straw. J. Plant Physiol., 163, 837-846. https://doi.org/10.1016/j.jplph.2005. 08.002

Schreiner, O., \& Reed H. S. (1907). The production of deleterious excretions by roots. Bull Torr Bot Club, 34, 279-303. https://doi.org/10.2307/2479157

Singh, P., Suman, A., \& Shrivastava, K. (2003). Isolation and identification of allelochemicals from sugarcane leaves. Allelopathy J., 12(1), 71-80.

Tew, T. L., White, W. H., Legendre, B. L., Grisham, M. P., Dufrene, E. O., Garrison, D. D., ... Miller, J.D., (2005). Registration of 'HoCP 96-540'sugarcane. Crop Sci., 45(2), 785-786. https://doi.org/10.2135/ cropsci2005.0785a

Viator, R. P., Johnson, R. M., Grimm, C. C., \& Richard, E. P. (2006). Allelopathic, autotoxic, and hormetic effects of postharvest sugarcane residue. Agronomy Journal, 98(6), 1526-1531. https://doi.org/10.2134/ agronj2006.0030

Webber, C. L. III, White, P. M. Jr., Landrum, D. S., Spaunhorst, D. J., \& Wayment, D. G. (2017b). Sugarcane field residue and bagasse allelopathic impact on vegetable seed germination. Journal of Agricultural Science, 9(11), 10-16. https://doi.org/10.5539/jas.v9n11p10

Webber, C. L. III, White, P. M. Jr., Landrum, D. S., Spaunhorst, D. J., \& Wayment, D. G. (2017c). Sugarcane Field Residue and Root Allelopathic Impact on Weed Seed Germination. Journal of Agricultural Science, in press.

Webber, C. L. III, White, P. M. Jr., Myers, D. L., Taylor, M. J., \& Shrefler, J. W. (2015a). Impact of kenaf (Hibiscus cannabinus L.) leaf, bark, and core extracts on germination of five plant species. Journal of Agricultural Science, 7(2), 93-98. https://doi.org/10.5539/jas.v7n2p93

Webber, C. L. III, White, P. M. Jr., Myers, D. L., Taylor, M. J., \& Shrefler, J. W. (2015b). Kenaf (Hibiscus cannabinus L.) impact on post-germination seedling growth. Journal of Agricultural Science, 7(12), 91-99. https://doi.org/10.5539/jas.v7n12p91

Webber, C. L. III, White, P. M. Jr., Spaunhorst, D. J., \& Petrie, E. C. (2017a). Comparative performance of sugarcane bagasse and black polyethylene as mulch for squash (Cucurbita pepo L.) production. Journal of Agricultural Science, 9(11), 1-9. https://doi.org/10.5539/jas.v9n11p1

Wu, H., Haig, T., Pratley, J., Lemerle, D., \& An, M. (2002). Distribution and exudation of allelochemicals in wheat (Triticum aestivum). J. Chem. Ecol., 26(9), 2141-2154. https://doi.org/10.1023/A:1005520500110

Wu, H., Pratley, J., Lemerle, D., \& Haig, T. (2001). Allelopathy in wheat (Triticum aestivum). Annals of Applied Biology, 139(1), 1-9. https://doi.org/10.1111/j.1744-7348.2001.tb00124.x

Wu, H., Pratley, J., Lemerle, D., An, M., \& Li, L. D. (2007). Autotoxicity of wheat (Triticum aestivum L.) as determined by laboratory bioassays. Plant and Soil, 296(1-2), 85-93. https://doi.org/10.1007/s11104-0079292-7

\section{Copyrights}

Copyright for this article is retained by the author(s), with first publication rights granted to the journal.

This is an open-access article distributed under the terms and conditions of the Creative Commons Attribution license (http://creativecommons.org/licenses/by/4.0/). 